\title{
The Effects Of Tax Sanction, Fiscal Services, Tax Knowledge, And Tax Amnesty On Taxpayer Compliance
}

\author{
Novi Darmayanti \\ \{novismile_ub@yahoo.com\} \\ University of Islamic Darul 'Ulum Lamongan
}

\begin{abstract}
This study was aimed to test the effects of Tax Sanctions, Tax Knowledge, Fiscal Services, and Tax Amnesty on Taxpayer Compliance. The population of this research was the taxpayers who work as civil servants in Sumberrejo sub-district of Bojonegoro district. A total of 38 respondents were selected using quota sampling as the samples. The results were found by using multiple linear regression analysis indicate that: (1) tax levy sanction does not have an effect on taxpayer compliance, (2) the tax knowledge variable does not affect taxpayer compliance, (3) the Fiscal service is significantly affected taxpayer compliance, (4) tax amnesty does not have a significant effect on taxpayer compliance.
\end{abstract}

Keywords: Fiscal Service, Tax Amnesty, Taxpayer Compliance

\section{Introduction}

As a country that has a population of more than 250 million people, Indonesia needs to do a variety of national development evenly in various sectors in order to create prosperity amid society. One of the sources of state income is to finance government spending and national development.

Tax is a mandatory contribution to the state-owned by an individual or entity (taxpayer) that is compelling based on the law, by not getting direct compensation and used for state needs for the greatest prosperity of the people [1].

Tax revenue is the largest source of state revenue in Indonesia. Looking at the significant role of tax for the source of state revenues, it is undeniable that the participation of the community, in this case, is a significant factor in state revenue, because the community is a taxpayer is the source of the tax itself. All taxpayers are no exception, state officials and civil servants are required to be obedient and obey to any tax regulations. For that as a reflection and role model of the community, officials and civil servants are required to obey the tax rules.

The tax collection system in Indonesia is complicated to carry out as expected. Therefore we need efforts to encourage the creation of a society that is obedient and obeys to tax regulations. The study of taxpayer compliance in fulfilling its tax obligations is significant because it affects the success of tax revenues. Several factors such as Tax Sanctions, Tax Knowledge, Fiscus Service, and Tax Amnesty have the possibility of influencing taxpayer compliance. 
As revealed by the research was found that tax sanctions influenced tax compliance [2]. Furthermore, tax knowledge affected motor vehicle taxpayer compliance [3]. Research conducted by [4], found the results that the quality of financial service partially gives significant effect on compliance with an individual taxpayer, then the research conducted by [5] found the result that the variable of tax amnesty influence taxpayer compliance.

Seeing that there are many differences from previous studies, in this study the researcher wants to reexamine these variables and add a new variable, tax amnesty which is the government's flagship policy at this time to increase tax revenue and compliance, but it is still rarely studied. The target of this study was focused on taxpayers in the Sumberrejo sub-district. The difference in this study was that the object of the research was specified in individual taxpayers among civil servants. Civil servants are chosen because as a reflection and role model for civil servants, they were required to be more obedient to tax regulations, for that researcher feels interested in knowing the level of compliance. The main problem faced in this study is that taxpayer compliance is still relatively low.

Based on the description above, the research questions can be formulated as follows: What are tax sanctions, tax knowledge, Fiscal Service, tax amnesty influence the individual taxpayer compliance among PNS in Sumberrejo sub-district.

\subsection{Definition of Tax}

According to [6], tax as people's contributions to the state treasury is based on the law (which can be forced) by not receiving counter-services, which can be directly shown and used to pay for public expenditure. According to [6], the tax functions are divided into two; they are:

1. The function of Financial (budgeted), is to enter as much money as possible into the state treasury, to finance state expenditures.

2. The function of Regulates (ruined), the tax is used as a tool to regulate society both in the economic, social, and political fields with specific objectives.

\subsection{Taxpayer}

According to [7], taxpayers are individuals or entities which according to the provisions of tax laws are determined to carry out tax obligations, including individual tax collectors or tax cutters.

[8] define taxpayers as persons or bodies who simultaneously fulfill subjective and objective requirements, people or entities that fulfill individual requirements are subject to tax but not necessarily taxpayers. Because of being taxpayers, the subject of the tax must also meet the objective requirements of receiving or obtaining taxable income.

\subsection{Income Tax Article 21}

[9] defines income tax $(\mathrm{PPh})$ as a tax imposed on private individuals or entities on income received or obtained in a tax year. Whereas the definition of income tax article 21 according to [1] is a tax on income in the form of salary, wages, honorarium, allowances, and other payments in name and in any form relating to work or position, services, and activities carried out by private persons subject to domestic tax, as referred to in article 21 of the income tax law.

\subsection{Taxpayer Compliance}


Siat and Toly (2013) explained that compliance is the motivation of a person, group or organization to do or not do something according to established rules, while taxpayer compliance is an obedient, disciplined, and loyal attitude made by individuals or groups towards legislation taxation in terms of fulfilling its tax obligations.

As a climate of awareness of compliance and fulfillment of tax obligations [10], states it is reflected in situations where (1) Taxpayers understand or try to understand all the provisions of tax laws and regulations. (2) Taxpayers complete the form thoroughly and clearly. (3). Taxpayers calculate the amount of tax owed correctly. (4). Taxpayers pay the tax due on time.

\subsection{Tax Sanctions}

Taxation sanctions according to [1] is a guarantee that the provisions of legislation - taxation invitations (taxation norms) will be obeyed. Alternatively, in other words, is a deterrent so that taxpayers do not violate taxation norms.

[1] also describes two types of sanctions in the tax law, namely (1). The administrative sanction is payment of losses to the state, divided into three types of sanctions, namely fines, interest, and increase. (2). criminal sanctions torture or suffering which becomes a final tool or legal fortress used by the tax authorities so that tax norms are obeyed. (3) kinds of criminal sanctions, namely: criminal fines, imprisonment, and imprisonment.

\subsection{Fiscal Services}

[11] argues that tax authorities are tax officers, so tax office services can be interpreted as a way of tax officers in assisting, managing, or preparing all the needs needed by someone who in this case is a taxpayer.

A quality fiscal according to [12] is a tax office that provides accurate information about matters relating to taxes and procedures for calculating them and does not carry out tax evasion or other actions that are not by applicable regulations and SOPs.

\subsection{Tax Amnesty}

According to [5], tax amnesty is an opportunity of limited time for individual taxpayers to pay a certain amount and in a particular time in the form of forgiveness of tax obligations (including interest and penalties) related to previous tax periods or certain periods without fear of criminal penalties.

[13] stated that Tax amnesty is a method used by the government to attract capital stored abroad by taxpayers both individual and corporate taxpayers to Indonesia. Individual and corporate taxpayers who report their assets and bring home to Indonesia will not be subject to sanctions but are only asked to pay ransoms whose amount has been determined by the government.

Implementation of tax amnesty which took place from the beginning of 2016 until the end of March 2017, wearing a ransom amount charged for assets that have not been reported on the 2015 SPT for those who submit SPT or all reported assets if the taxpayer has never reported (disclosed) the assets owned. The amount of ransom is adjusted to the rate and period (month) that has been set.

\subsection{Development of Hypotheses}


a. Effect of Tax Sanctions on Taxpayer Compliance with Civil Servants

[2] researched KPP Tigarksa Tangerang with the title of analysis of factors that influence the level of individual taxpayer obligations. They found out tax sanctions influence taxpayer compliance. The results of the Dharma and Ariyanto research were supported by [5] on the effect of sunset policy, tax amnesty, and tax sanction on taxpayer compliance (empirical study at KPP Pratama Jakarta Kembangan) which also found that tax sanctions had a positive effect on the level of tax compliance.

b. Effect of Tax Knowledge on Civil Servants Tax Compliance

[3] found the effect of taxpayer awareness, tax knowledge, taxation sanctions and public service accountability on motor vehicle taxpayer compliance. It showed the results that knowledge of taxation affected taxpayer compliance.

c. Effect of Tax Knowledge on Civil Servant Taxpayer Compliance

[3] found the effect of awareness of taxpayers, knowledge of taxation, taxation sanctions and accountability of public services on motor vehicle taxpayer compliance, showing the results that knowledge of taxation affects taxpayer compliance.

d. Effect of Tax Amnesty on Compliance with Taxpayers among Civil Servants

[5] found the influence of sunset policy, tax amnesty and tax penalties on tax compliance in KPP Pratama Jakarta Kembangan and found that the variable tax amnesty influences tax compliance.

\section{Methods}

This study uses a quantitative approach, which was carried out in Sumberrejo Bojonegoro sub-district. The objects are individual taxpayers who work as civil servants. The object in this study was individual taxpayers with PNS status from the group I to group IV in the Sumberrejo sub-district of Bojonegoro district. The results of this research are all civil servants in the Bojonegoro sub-district, which consists of sub-district officials/ staff and village secretaries. This study uses saturated sampling with the number of people 38 taxpayers were sampled. The research data obtained by using a questionnaire (questionnaire). To measure the opinions of respondents, the Likert scale is used which contains five response prefixes or a 5point Likert scale. The analytical method used is the analysis of multiple linear regression.

\section{$3 \quad$ Results}

Respondents in this study are taxpayers who work as civil servants in the Sumberrejo subdistrict of Bojonegoro district with 38 respondents, all of whom were sampled. The researcher spread 38 questionnaires, and the results of 38 questionnaires could be used as research data. The character of respondents is grouped according to gender, age, job title, and ownership of Taxpayer Registration Number (NPWP).

\subsection{Descriptive statistics}

From the analysis of the data, it can be seen that the total number of respondents or data is 38 with a valid condition which means it is valid for processing. Values for each variable is the 
variable tax penalties have answers lowest value is worth 13, and the answer is worth 34 so that the highest value obtained answer mean score 24.79. The tax knowledge variable has the lowest value answer of 18 , and the highest value answer is 35 so that the average score is 27.13 . Then the lowest value of the tax authorities service variable is 21 , and the answer to the highest score is 30 , the average score for this variable is 24.50 . The tax amnesty variable has the lowest value answer worth 17, and the highest value answer is 36 with an average score of 29.79 .

\subsection{Test of Validity}

Validity test is measured to measure the validity of a questionnaire; a questionnaire is said to be valid if the question in the questionnaire can indicate the variable. The analysis was carried out on all items in the questionnaire with the provision that if the value of $\mathrm{KMO}>0.5$ then all items are declared valid so that they are worthy of further analysis.

From the data analysis results obtained that KMO MSA value for the variable (1) Tax sanctions are 0.781 , (2) Knowledge of taxation 0.755, (3) Service of tax authorities 0.552, (4) Tax amnesty 0.558 (5). Taxpayer compliance 0.558 . of the five variables, it can be seen that the MSO KMO value is more excellent than 0.5 so that it can be stated that all instrument variables are valid.

\subsection{Test of Reliability}

This study measures the reliability using the Cronbach's Alpha coefficient value; a senior cake said to be reliable if it has the value of Cronbach's Alpha $>0.6$. From the data analysis results obtained that Cronbach's Alpha values for each variable, namely (1) Tax sanctions are $0.794,(2)$ Knowledge of taxation 0.859 , (3) Fiscal services 0.684 , (4) Tax amnesty 0.829 (5). Taxpayer compliance 0.844 . Of the five variables, it can be seen that the value of Cronbach's Alpha is more excellent than 0.6 so that it can be stated that all variable instruments are reliable.

\subsection{Test of Multicollinearity}

This test is intended to detect the existence of a causal relationship between two or more independent variables, or there is the fact that two explanatory variables or more together are influenced by the third variable that is outside the model. To detect multicollinearity, the value of the variance inflation factor (VIF) cannot be more than 10.

Based on the results of the analysis of data showed that VIF for variable tax penalties is $1,118<10$, variable tax knowledge is $1.1564<10$, the variable service tax authorities is 1.619 $<10$ and variable tax amnesty is $1.222<10$. Thus, it can be concluded that there are no multicollinear symptoms among independent variables.

\subsection{Test of Heteroscedasticity}

To detect the presence or absence of heteroscedasticity on a model can be seen from the scatterplot pattern image model. If the spread of data points is not patterned, the data points spread above and below or around the number 0 , and data points do not gather just above or just below, it can be said that the model does not occur symptoms of heteroscedasticity. From the scatterplot analysis of the data, it can be seen that the dots randomly spread and spread well 
on top at the bottom of zeros. Thus, it can be concluded that heteroscedastic does not occur in this model.

\section{6 t-test}

This test is conducted to determine whether the independent variables partially or individually affect the dependent variable. In this study, four independent variables were used, namely Tax Sanctions, Tax Knowledge, Fiscal Services, Tax Amnesty. The dependent variable is taxpayer compliance. The regression test results are shown in table 1.

Table 1. Multiple Regression Test Results

\begin{tabular}{lccll}
\hline Variable & $\mathrm{t}$ count & $\mathrm{t}$ table & Sig & Information \\
\hline Tax Sanctions & 0.296 & 1,694 & 0.769 & No effect \\
Taxation Knowledge & 1,054 & 1,694 & 0,299 & No effect \\
Fiscal Services & 4,205 & 1,694 & 0,000 & Positive influence \\
Tax Amnesty & $-0,553$ & 1,694 & 0.584 & No effect \\
\hline
\end{tabular}

Based on table 1, Variable of tax sanctions has a value of $t_{\text {count }}$ as large as 0.296 and a sig value of 0.769 . Value $t_{\text {count }}<t_{\text {table }}(0.296<1.69389)$ and the value of sig $>0.05(0.769>0.05)$; it can be concluded that the variable tax sanction does not affect taxpayer compliance. The straightforward application of tax sanctions makes taxpayers underestimate existing sanctions so as not to make taxpayers a deterrent to violating tax regulations, even though the sanctions given are quite severe, but in reality, their application is far from being firm.

Based on table 1, Variable knowledge of taxation has amounting value $t_{\text {count }}$ to 1,054 and Sig value of 0,299 . The value of $t_{\text {count }}<t_{\text {table }}(1.054<1.69389)$ and sign $>0.05(0.299>0.05)$; it can be concluded that the knowledge variable of taxation does not affect taxpayer compliance. Payment of taxes borne by the government makes taxpayers PNS feel that knowledge of taxes is not needed anymore; in fact, many taxpayers are civil servants who do not know how to calculate the tax payable.

Based on table 1, The Fiscal service variable has a value $t_{\text {count }}$ amounting to 4,205 and sign value of 0,000 . The value of $t_{\text {count }}<t_{\text {table }}(4,205>1,69389)$ and sign $<0,05(0,000>0,05)$, it can be concluded that the tax authorities service variable affects taxpayer compliance. Good, fast and appropriate services can encourage taxpayer compliance always to fulfill their tax obligations.

The tax Amnesty variable has value $\mathrm{t}_{\text {count }}$ amounting $\mathrm{t}_{\mathrm{obs}}-0.553$ and Sig value of 0.584 . The value of $\mathrm{t}_{\text {count }}<\mathrm{t}_{\text {table }}(-0.553<1.69389)$ and sign $>0.05(0.584>0.05)$, it can be concluded that the tax amnesty variable does not affect taxpayer compliance.Payments for civil servant taxes borne by the government make the tax amnesty policy not very attractive to civil servants.

\section{Conclusion}

This research finds the effect of Tax Sanctions, Tax Knowledge, Fiscal service and Tax Amnesty on taxpayer compliance. This research was conducted on individual taxpayers who work as civil servants in the sub-district of Sumberrejo in Bojonegoro Regency. Based on the results of the analysis carried out by the researcher, this conclusion can be drawn (1) The tax 
sanction variable has no effect on tax compliance, (2) Variable knowledge of taxation does not affect taxpayer compliance, (3) The tax Fiscal service variable has a positive and significant effect on taxpayer compliance. This means that the better service provided, the higher the level of tax compliance, (4) The tax amnesty variable does not influence tax compliance.

\section{Reference}

[1] Mardiasmo, Taxation. Yogyakarta: Andi Offset, 2016.

[2] M. T. Dharma and S. Ariyanto, 'Analisis Faktor-Faktor Yang Memengaruhi Tingkat Kepatuhan Wajib Pajak Orang Pribadi Di Lingkungan Kantor Pelayanan Pajak Pratama, Tigaraksa Tangerang', Binus Bus. Rev., vol. 5, no. 2, pp. 497-509, 2014.

[3] K. E. Susilawati and K. Budiartha, 'Pengaruh Kesadaran Wajib Pajak, Pengetahuan Pajak, Sanksi Perpajak, dan Akuntabilitas Pelayanan Publik Pada Kepatuahan Wajib Pajak Kendaraan Bermotor', E-Jurnal Akunt. Univ. Udayana, vol. 4, no. 2, pp. 345-357, 2013.

[4] C. Jotopurnomo and Y. Mangoting, 'Pengaruh Kesadaran Wajib Pajak, Kualitas Pelayanan Fiskus, Sanksi Perpajakan, Lingkungan Wajib Pajak Berada terhadap Kepatuhan Wajib Pajak Orang Pribadi di Surabaya', Tax Account. Rev., vol. 1, no. 1, pp. 49-54, 2013.

[5] Ngadiman and D. Huslin, 'Pengaruh Sunset Policy, Tax Amnesty, Dan Sanksi Pajak Terhadap Kepatuhan Wajib Pajak (Studi Empiris di Kantor Pelayanan Pajak Pratama Jakarta Kembangan)', J. Akunt., vol. 19, no. 2, pp. 225-241, 2015.

[6] S. Erly, Tax Law. Jakarta: Salemba Empat, 2011.

[7] M. Siahaan, Hukum Pajak Elementer. Yogyakarta: Graha Ilmu, 2010.

[8] S. Rochmat and S. D. Kania, Principles and Basic of Taxation. Bandung: Refika Aditama, 2010.

[9] S. Adrian, Tax Law. Jakarta: Sinar Grafika, 2013.

[10] S. K. Rahayu, Indonesian Taxation Concepts and Formal Aspects. Yogyakarta: Graha Ilmu, 2010.

[11] O. L. Winerungan, 'Sosialisasi Perpajakan, Pelayanan Fiskus Dan Sanksi Perpajakan Terhadap Kepatuhan WPOP Di KPP Manado Dan KPP Bitung', J. EMBA, vol. 1, no. 3, pp. 960-970, 2013.

[12] E. L. E. Wurianti and A. Subardjo, 'Analisis Faktor Faktor Yang Mempengaruhi Kepatuhan Wajib Pajak Di Wilayah Kpp Pratama', J. Ilmu Ris. Akunt., vol. 4, no. 6, pp. 1-15, 2015.

[13] Suyanto, P. P. L. A. Intansari, and S. Endahjati, 'Tax amnesty', J. Akunt., vol. 4, no. 2, pp. 9-22, 2016. 